\title{
Agrometeorological models for estimating sweet cassava yield ${ }^{1}$
}

\author{
Victor Brunini Moreto², Lucas Eduardo de Oliveira Aparecido ${ }^{3}$, \\ Glauco de Souza Rolim², José Reinaldo da Silva Cabral de Moraes ${ }^{2}$
}

\section{ABSTRACT}

Brazil is the fourth largest producer of cassava in the world, with climate conditions being the main factor regulating its production. This study aimed to develop agrometeorological models to estimate the sweet cassava yield for the São Paulo state, as well as to identify which climatic variables have more influence on yield. The models were built with multiple linear regression and classified by the following statistical indexes: lower mean absolute percentage error, higher adjusted determination coefficient and significance ( $p$-value $<0.05$ ). It was observed that the mean air temperature has a great influence on the sweet cassava yield during the whole cycle for all regions in the state. Water deficit and soil water storage were the most influential variables at the beginning and final stages. The models accuracy ranged in $3.11 \%, 6.40 \%, 6.77 \%$ and $7.15 \%$, respectively for Registro, Mogi Mirim, Assis and Jaboticabal.

KEYWORDS: Manihot esculenta; crop modeling; climatology.

\section{INTRODUCTION}

One of the three main human food sources in the world, besides rice and maize, roots of cassava (Manihot esculenta Crantz) present a high nutritional value and are considered an important food complement, playing a fundamental role for food security in tropical regions, which are mainly represented by developing countries (FAO 2012, Gabriel et al. 2014).

Cassava is a Brazilian native plant that belongs to the Euphorbiaceae family, and it is a valuable crop, mainly for the economies of countries in development, due to the versatility of in natura and

\section{RESUMO}

Modelos agrometeorológicos

para estimar o rendimento de mandioca doce

O Brasil é o quarto maior produtor mundial de mandioca, tendo as condições climáticas como principais fatores na regulação de sua produção. Objetivou-se desenvolver modelos agrometeorológicos para estimar a produtividade de mandioca doce para o estado de São Paulo, bem como identificar quais variáveis climáticas exercem maior influência sobre a produtividade. Os modelos foram construídos com regressão linear múltipla e classificados pelos seguintes índices estatísticos: menor erro percentual absoluto médio, maior coeficiente de determinação ajustado e significância ( $\mathrm{p}$-valor $<0.05$ ). Identificou-se que a temperatura média do ar tem grande influência no rendimento da mandioca durante todo o ciclo, para todas as regiões do estado. O déficit hídrico e o armazenamento de água no solo foram as variáveis mais influentes nos estágios inicial e final. A precisão dos modelos variou em 3,11\%, 6,40\%, 6,77\% e 7,15\%, respectivamente para Registro, Mogi Mirim, Assis e Jaboticabal.

PALAVRAS-CHAVE: Manihot esculenta; modelagem de culturas; climatologia.

industrialized sub-products and by-products (Zanetti et al. 2014).

Brazil is the fourth largest producer of cassava in the world, after Nigeria, Thailand and Indonesia. In the growing season of 2016, 23.71 million tons of cassava roots were harvested. Currently, the Pará state leads the cassava production in Brazil, followed by Paraná and Bahia (Conab 2017). The southeast region is responsible for $11 \%$ of all the cassava produced in the country, being São Paulo the most productive state, with about 1.4 million tons of cassava per year. Nevertheless, the production of the São Paulo state has been decreasing during the past few years. With respect to production, São Paulo stands out due to its 
great average yield (23.59 $\left.\mathrm{t} \mathrm{ha}^{-1}\right)$, while in the Pará state the average yield is $14.62 \mathrm{tha}^{-1}$ (IBGE 2016). In the São Paulo state, $13 \%$ of the cassava production areas are devoted to sweet cassava (Valle \& Lorenzi 2014).

The most influential factors that affect the sweet cassava quality are the genetic composition of the cultivar (Valle et al. 2004) and the environmental conditions. The sweet cassava quality is determined by various factors, especially low cyanogenic levels and low acid content, which reduce the risk of poisoning by cyanide, a highly toxic chemical substance (Mezzete et al. 2009).

Establishing relations between plant phenology and environmental conditions (for example, air temperature and soil moisture) will aid in defining technical agronomic criteria for cassava crops, such as planting spacing and mechanization (Rós et al. 2011).

Few studies have analyzed the influence of climate effects on cassava crops. Lahai et al. (1999) observed different responses of cassava development and production under different conditions of sunshine hours, air temperature and rainfall. Cassava is tolerant to conditions of long dry periods and high precipitation; however, it is necessary to manage soil drainage conditions. Soils with poor drainage are susceptible to waterlogging, what may lead to root rot and substantial losses in yield (Tremacoldi 2016). Normally cultivated on low fertility soils, and adaptable to climate variability, cassava is considered as the main example of a sustainable food of the 21th century (Valle et al. 2007).

Air temperatures between $25^{\circ} \mathrm{C}$ and $29^{\circ} \mathrm{C}$ and annual rain averages between 1,000 and $1,500 \mathrm{~mm}$ are considered optimal conditions for cassava development. Commonly cultivated under rainfed systems, rain events are the most limiting factors for its production (Alves 2006).

Agrometeorological models are helpful tools for decision makers about agricultural activities. Incorporating climate information to the crop production allows the demonstration of its influence during the crop cycle. In addition, this information is used to develop estimation models for crop quality and yield (Moreto \& Rolim 2015).

This research aimed at the development of agrometeorological models to estimate the annual yield of sweet cassava for the São Paulo state, as well as to identify and describe the influence of climate during the crop cycle.

\section{MATERIAL AND METHODS}

The climatic data of the producing regions (Figure 1) were provided by the Instituto Agronômico de Campinas, in Campinas, São Paulo state, Brazil. These regions correspond to $80.3 \%$ of the total cassava production in the São Paulo state (São

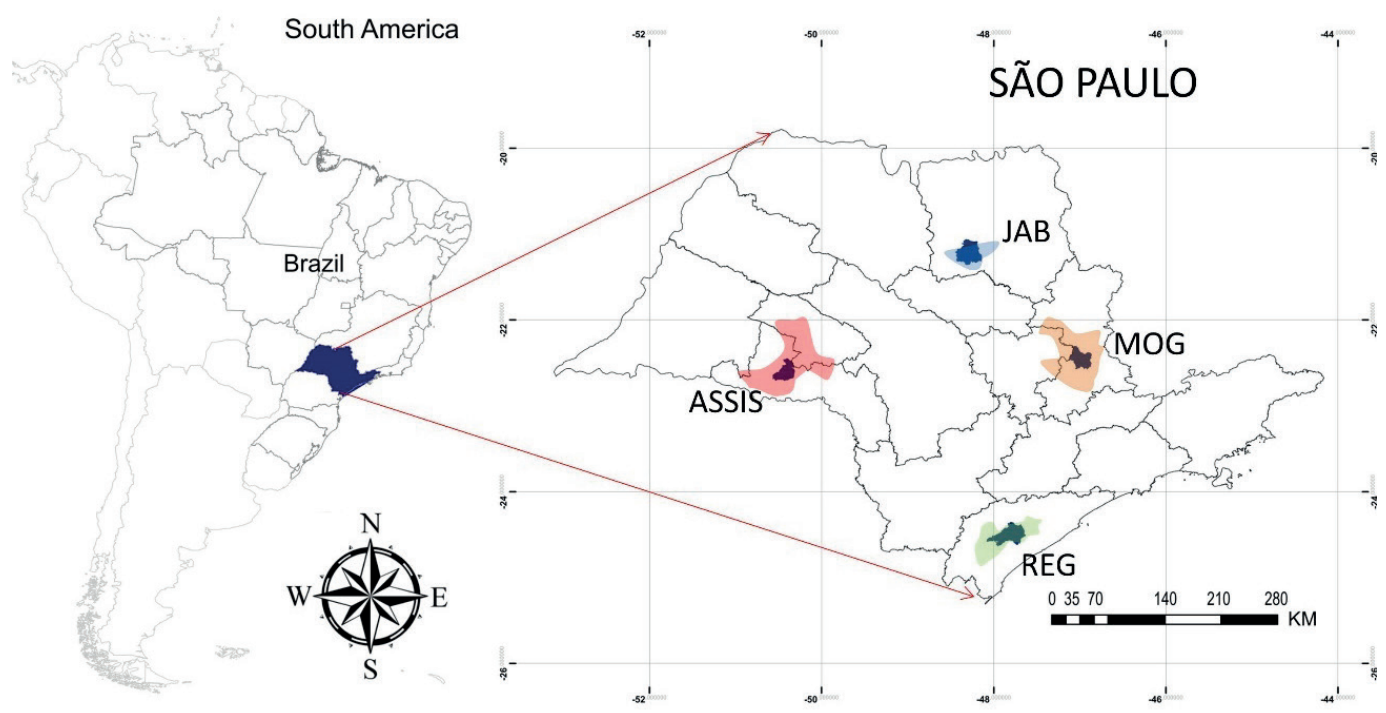

Figure 1. Map of the main productive regions of sweet cassava in the São Paulo state. JAB: Jaboticabal; MOG: Mogi Mirim; REG: Registro. 
Paulo 2008). Monthly precipitation and mean air temperature from 1999 to 2014 were used to calculate the potential evapotranspiration, using the Thornthwaite (1948) method (equations 1, 2, 3, 4 and 5). This method, even though it is not the most indicated for São Paulo, is the one with the highest accuracy, when using a database that is limited in terms of climatic variables (Caporusso \& Rolim 2015):

$\mathrm{PET}=\mathrm{ETp} \times \mathrm{COR}$

$\left\{\begin{array}{l}\text { ETp }=16 \times\left(10 \times \frac{\mathrm{Tn}}{\mathrm{I}}\right)^{\mathrm{a}}, \text { if } 0 \leq \mathrm{Tm}<26.5^{\circ} \mathrm{C} \\ \text { ETp }=-415.85+32.24 \times \mathrm{Tm}-0.43 \mathrm{Tm}^{2}, \text { if } \mathrm{Tm} \geq 26.5^{\circ} \mathrm{C}\end{array}\right.$

$\mathrm{I}=\sum_{\mathrm{n}=1}^{12}(0.2 \times \mathrm{Tn})^{1.514}$

$\mathrm{a}=0.49239+1.7912 \times 10^{-2} \times \mathrm{I}-7.71 \times 10^{-5} \times \mathrm{I}^{2}+6.75 \times 10^{-7} \times \mathrm{I}^{3}$

$\mathrm{COR}=\frac{\mathrm{N}}{12} \times \frac{\mathrm{NDP}}{30}$

where $P E T$ is the potential evapotranspiration $\left(\mathrm{mm}\right.$ month $\left.^{-1}\right)$; ETp the standard evapotranspiration; COR the correction factor, in function of the actual number of days and the photoperiod of the month; $T m$ the mean air temperature of the month $n$; $I$ the index that expresses the heat level of the region; $a$ the regional thermal index; $N D P$ the number of days of the period; and $N$ the mean photoperiod of the month.

The potential evapotranspiration was used in the sequential water balance model (Thornthwaite \& Mather 1955) to generate information of monthly water deficit, water excess and soil water storage, using the available water capacity (AWC) of $100 \mathrm{~mm}$ (equation 6). For soil texture, loamy soils for all regions and an average cassava crop root depth of $50.0 \mathrm{~cm}$ (FAO 2013) were used. According to Doorenbos \& Kassam (1994), to create a practical criteria, the average available water capacity for clay and loamy soils can be estimated as $2.0 \mathrm{~mm} \mathrm{~cm}^{-1}$.

$$
\mathrm{AWC}=\overline{\mathrm{AWC}} \times \mathrm{Zr}
$$

where $\overline{A W C}$ is the average available water capacity $\left(\mathrm{mm} \mathrm{cm} \mathrm{cm}^{-1}\right)$ and $\mathrm{Zr}$ the average cassava root depth (cm). The annual yield data for sweet cassava were obtained from the lnstituto de Economia Agrícola, in São Paulo, for the period of 1998 to 2014.

The use of multiple linear regression requires the selection and combination of independent variables for the development of significant models. For this step, the method proposed by Walpole et al. (2012), which tests all possible combinations between the pre-selected independent variables, was used in the analysis.

The independent variables mean air temperature, precipitation, water deficit, water excess and soil water storage were used to develop the models with multiple linear regression (equation 7). A period of 10 to 12 years was used for calibration and 4 years for testing. As cassava has a cycle of up to 15 months (Figure 2), 15 monthly datasets were used for each meteorological variable, totaling $(5 \times 15)=75$ possible independent variables to use in the models for each location:

$$
\mathrm{Y}=\mathrm{ax} \mathrm{X}_{1}+\mathrm{bx} \mathrm{X}_{2}+\mathrm{c} \mathrm{xX}_{3}+\ldots+\mathrm{LC}
$$

where $Y$ is the yield, in $\mathrm{tha}^{-1} ; a, b, c, \ldots$ the angular coefficients; $X_{1}, X_{2}, X_{3}, \ldots$ the selected monthly meteorological variables; and $L C$ the linear coefficient.

Models with up to $3 \mathrm{Xn}$ in the equation were tested, totaling 156,348 possible equations

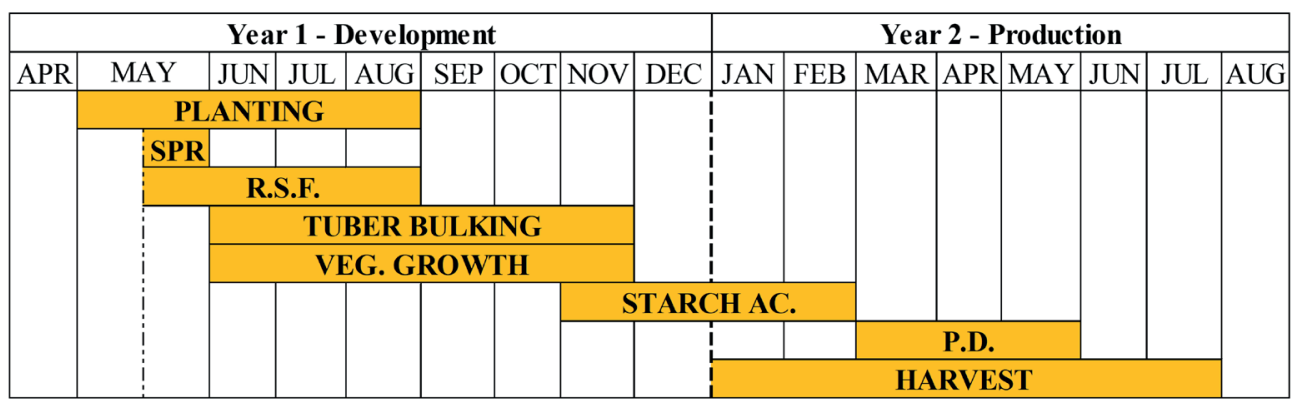

Figure 2. Mean phenology of sweet cassava for the São Paulo state. SPR: sprouting; R.S.F.: root system formation; VEG.: vegetative; AC.: accumulation; P.D.: physiological dormancy. 
for estimating the sweet cassava annual yield. All monthly meteorological variables may have a relative importance for the crop development and production, but we searched for the most important ones. The selection was based on coefficients of significance to select the variables $(\mathrm{t}<0.05)$ and regressions $(\mathrm{F}<0.05)$, as well as the minimization of the mean absolute percentage error (MAPE) and maximization of the adjusted $\mathrm{R}^{2}$ (equations 8 and 9 ):

$$
\begin{aligned}
& \operatorname{MAPE}(\%)=\frac{\sum_{\mathrm{i}=1}^{\mathrm{N}}\left(\left|\frac{\text { Yest }_{\mathrm{i}}-\text { Yobs }_{\mathrm{i}}}{\text { Yobs }_{\mathrm{i}}}\right| \times 100\right)}{\mathrm{N}} \\
& \text { Adjusted } \mathrm{R}^{2}=\left[1-\frac{\left(1-\mathrm{R}^{2}\right) \mathrm{x}(\mathrm{N}-1)}{\mathrm{N}-\mathrm{k}-1}\right]
\end{aligned}
$$

where Yest ${ }_{i}$ is the estimated yield at the year $i$; Yobs the observed yield; $N$ the number of data; and $k$ the number of independent variables in the regression.

For evaluating the angular coefficients of the Xs of the models, an analysis was conducted to remove the multicollinearity between the Xs (mean air temperature, precipitation, water deficit, water excess and soil water storage). Multicollinearity is not an issue when the interest is just estimation. However, if the analysis of the angular coefficients of the variables is also conducted, multicollinearity may cause bias in these coefficients by not expressing the influence of these variables on the model (Gujarati \& Porter 2011).

\section{RESULTS AND DISCUSSION}

Among the regions with the highest production in the São Paulo state, climate variability is responsible for the widest range of variation in yield. Comparing the Registro and Jaboticabal regions, these present a similar average yield $\left(14.0 \mathrm{t} \mathrm{ha}^{-1}\right)$, but Registro has a slightly higher accumulated water deficiency (more than $100 \mathrm{~mm}$ ), which may decrease yield, and the inverse occurs for Jaboticabal, where, even in seasons with a high water deficiency level, yield is maintained above the average. In Assis and Mogi Mirim, the average yield is $18 \mathrm{t} \mathrm{ha}^{-1}$, and the variability among seasons did not follow a pattern, with dry and wet seasons presenting both high and low yields, what indicates that the timing and extension of these periods (dry and/or wet) during the crop cycles could influence the final yield (Figure 3 ).
For each region, about 57,000 model combinations were generated. Subsequently, the combinations that presented multicollinearity between the independent variables were removed. For the Jaboticabal region, 5,441 equations demonstrated multicollinearity, while the remaining ones $(51,784)$ represent the possible models to estimate sweet cassava yield. From these models, the better ones were selected and classified looking for a low mean absolute percentage error, adjusted $\mathrm{R}^{2}$ near 1 and $\mathrm{p}<0.05$.

Based on the viable models, the five best ranked (Table 1) were selected, following the criteria of significant models ( $p$-value $<0.05$ ), lowest mean absolute percentage error and adjusted $\mathrm{R}^{2}$ closest to 1.00 for the tests (validation).

Empirical models are based purely on quantitative interactions between the observed variables considered. These modeling methods are normally derived from regression analysis and are highly dependent on databases with ample data, and long data series may be sufficient to achieve an accurate response of a situation (Corrêa et al. 2011). A series of 15 years of data was used to develop the models and, even though the availability of cassava production data was scarce, it was still possible to achieve accurate models for the specific productive regions of the São Paulo state. In general, the models presented a good accuracy, with mean absolute percentage error values ranging from the best $[3.11 \%$ (Registro)] to the worst [18.72\% (Assis)], in the tests. For example, if we consider an average yield (15 years) of $14.42 \mathrm{t} \mathrm{ha}^{-1}$ for Registro, the model error is $0.45 \mathrm{t} \mathrm{ha}^{-1}$ or $450 \mathrm{~kg}$, with a precision of 0.87. Similar results were obtained for Assis, with $18.38 \mathrm{t} \mathrm{ha}^{-1}$ of average yield, with a model error of about $3.44 \mathrm{t} \mathrm{ha}^{-1}$ and precision of 0.71 . Calibrated mean absolute percentage error values ranged from $2.04 \%$ (Mogi Mirim) to $7.10 \%$ (Registro). Even with a short data series, calibration was satisfactory (Figure 4).

Models that associated mean air temperature and water balance in their calculations presented a higher accuracy than others; likewise, models that use only primary variables, i.e., mean air temperature and precipitation, may also be used, taking into consideration that accuracy may be lower.

Agrometeorological models to estimate yield are used as planning tools for the short and/or medium terms, as, for example, for creating a budget for 
selling and yield destination (Rijks \& Baradas 2000). The models developed in this study can estimate the cassava yields before harvest (Table 2). However, the best models for each region vary for anticipation time; for example, for Jaboticabal, the anticipation is of three months before late harvest (July). The Mogi Mirim models were not able to anticipate it, as the models use variables from July in their estimations.

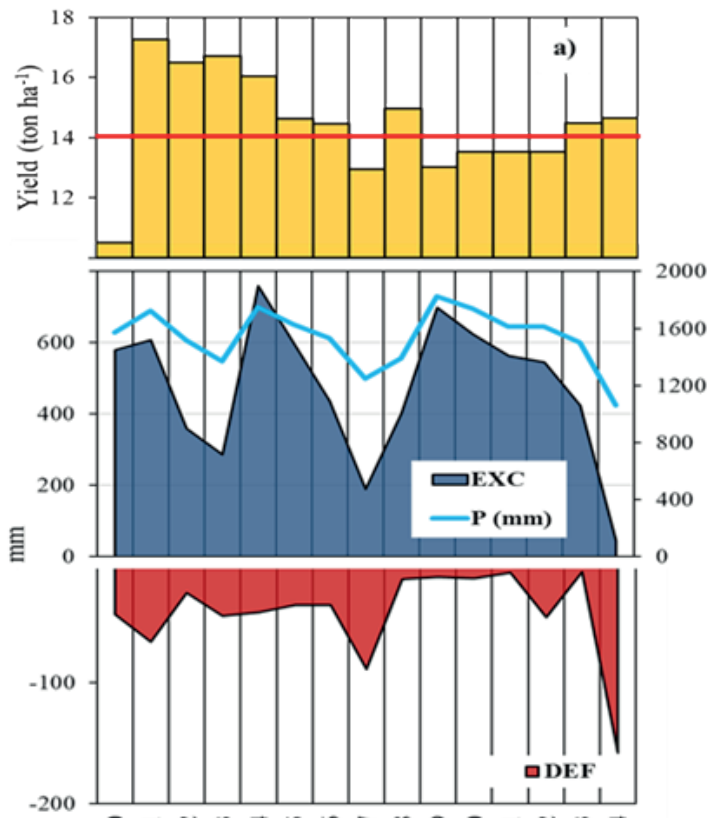

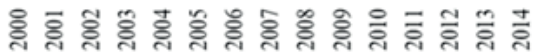

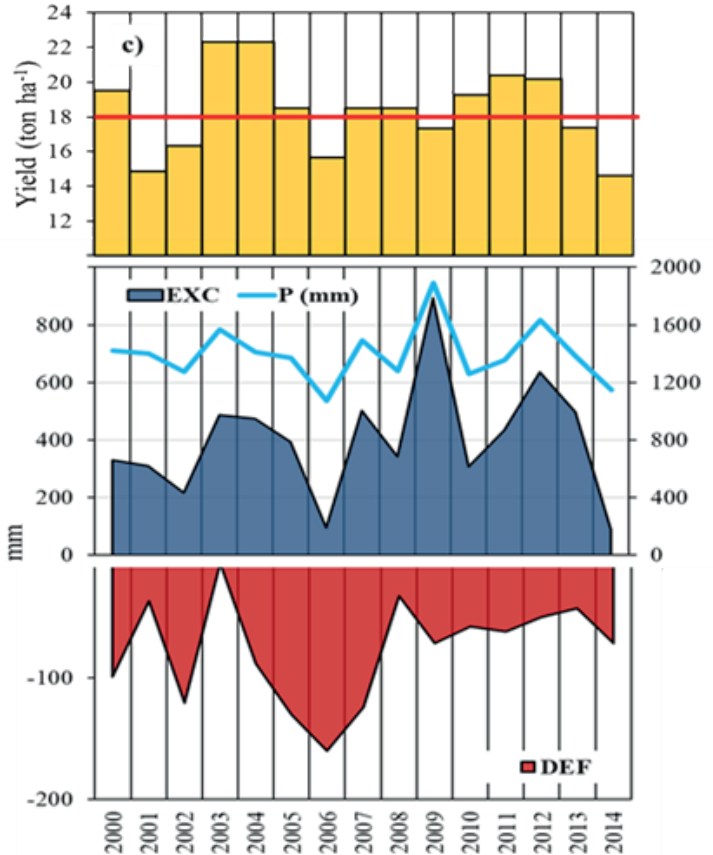

Using the sensitivity analysis, it was possible to identify the most influential meteorological variables for the sweet cassava yield of the São Paulo state. For this analysis, the ten best models were selected for each region and the angular coefficients of each independent variable were analyzed (Figure 5). The coefficients also indicate if the influence is direct $(+)$ or inverse (-), in relation to the sweet cassava yield.
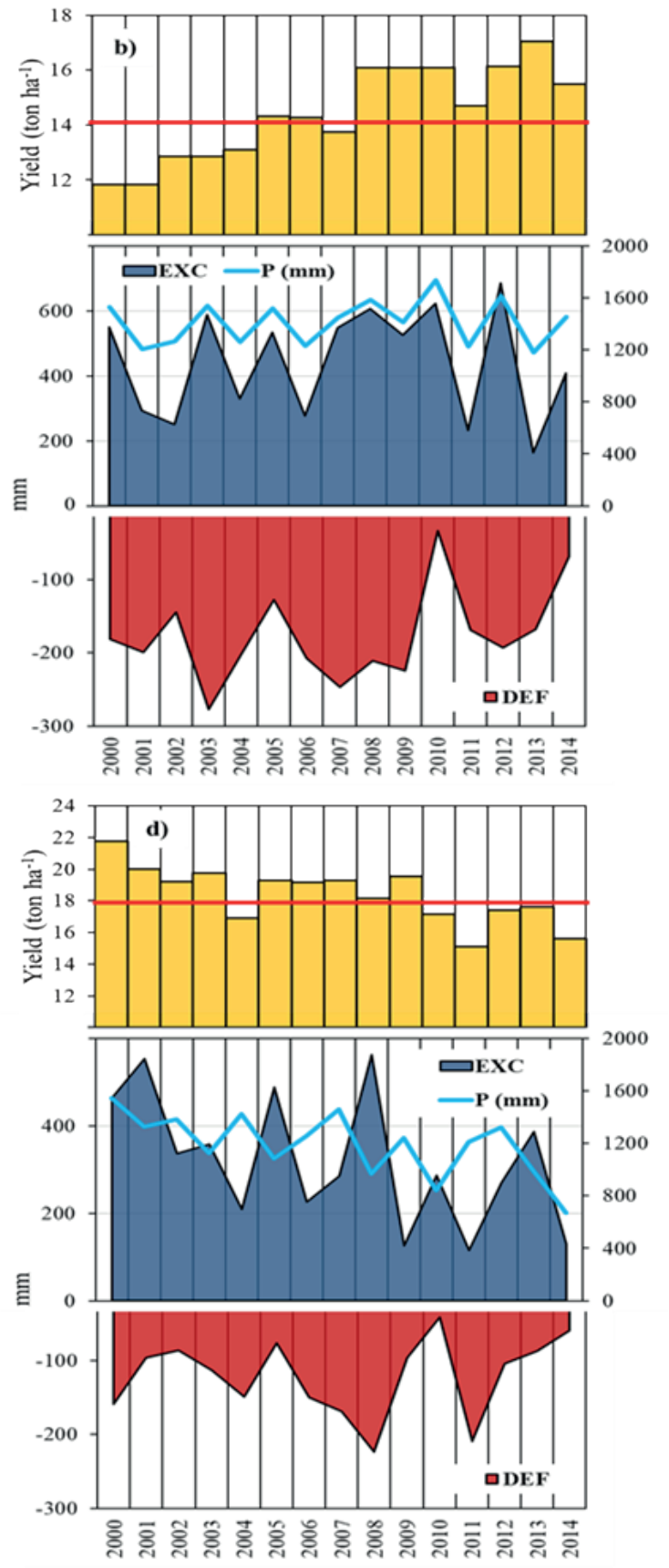

Figure 3. Water balance components: deficit (DEF), excess (EXC) and precipitation (P) variability, during the cassava crop seasons, for the São Paulo state. a) Registro; b) Jaboticabal; c) Assis; d) Mogi Mirim. The red line indicates the average yield. 
Table 1. Agrometeorological models to estimate the sweet cassava yield for the most important producing regions of the São Paulo state.

\begin{tabular}{|c|c|c|c|c|c|c|}
\hline & \multirow{2}{*}{ Models } & \multirow{2}{*}{ p-value } & \multicolumn{2}{|c|}{ Calibration } & \multicolumn{2}{|r|}{ Tests } \\
\hline & & & MAPE & Adjusted $\mathrm{R}^{2}$ & MAPE & Adjusted $\mathrm{R}^{2}$ \\
\hline \multicolumn{7}{|c|}{ Jaboticabal } \\
\hline 1 & Yield $=0.029 * \mathrm{SWS}_{\mathrm{APR}-\mathrm{Y} 2}-1.974 * \mathrm{Tm}_{\mathrm{JAN}-\mathrm{Y} 2}+0.041 * \mathrm{SWS}_{\mathrm{JUN}-\mathrm{Y} 1}+58.067$ & 0.029 & 4.61 & 0.58 & 7.15 & 0.82 \\
\hline 2 & Yield $=-2.415 * \mathrm{Tm}_{\mathrm{JAN}-\mathrm{Y} 2}+0.039 * \mathrm{SWS}_{\mathrm{JUN}-\mathrm{Y} 1}+0.877 * \mathrm{Tm}_{\mathrm{NOV}-\mathrm{Y} 1}+49.073$ & 0.044 & 5.24 & 0.52 & 7.25 & 0.85 \\
\hline 3 & Yield $=-1.921 * \mathrm{Tm}_{\mathrm{JAN}-\mathrm{Y} 2}-0.039 * \mathrm{DEF}_{\mathrm{JUN}-\mathrm{Y} 1}-1.09 * \mathrm{Tm}_{\mathrm{JAN}-\mathrm{Y} 1}+87.268$ & 0.028 & 5.25 & 0.58 & 7.96 & 0.73 \\
\hline 4 & Yield $=-1.959 * \mathrm{Tm}_{\mathrm{JAN}-\mathrm{Y} 2}-0.031 * \mathrm{SWS}_{\mathrm{JUN}-\mathrm{Y} 1}-0.896 * \mathrm{Tm}_{\mathrm{JAN}-\mathrm{Y} 1}+81.223$ & 0.028 & 5.11 & 0.58 & 8.22 & 0.80 \\
\hline 5 & Yield $=-2.069 * \mathrm{Tm}_{\mathrm{JAN}-\mathrm{Y} 2}+0.042 * \mathrm{SWS}_{\mathrm{JUN}-\mathrm{Y} 1}+0.473 * \mathrm{Tm}_{\mathrm{APR}-\mathrm{Y} 1}+52.471$ & 0.047 & 5.60 & 0.51 & 8.76 & 0.61 \\
\hline \multicolumn{7}{|c|}{ Assis } \\
\hline 1 & Yield $=0.025 * \mathrm{P}_{\mathrm{APR}-\mathrm{Y} 2}+0.015 * \mathrm{P}_{\mathrm{AUG}-\mathrm{Y} 1}+1.047 * \mathrm{Tm}_{\mathrm{JUL}-\mathrm{Y} 1}-2.841$ & 0.029 & 6.15 & 0.58 & 8.08 & 0.69 \\
\hline 2 & Yield $=0.045 * \mathrm{SWS}_{\mathrm{APR}-\mathrm{Y} 2}+0.038 * \mathrm{SWS}_{\mathrm{AUG}-\mathrm{Y} 1}+0.931 * \mathrm{Tm}_{\mathrm{JUL}-\mathrm{Y} 1}-3.023$ & 0.036 & 6.50 & 0.55 & 6.77 & 0.49 \\
\hline 3 & Yield $=0.026 * \mathrm{P}_{\mathrm{APR}-\mathrm{Y} 2}+1.140 * \mathrm{Tm}_{\mathrm{FEB}-\mathrm{Y} 2}+1.376 * \mathrm{Tm}_{\mathrm{JUL}-\mathrm{Y} 1}-36.118$ & 0.032 & 6.14 & 0.57 & 9.14 & 0.80 \\
\hline 4 & Yield $=0.029 * \mathrm{P}_{\mathrm{APR}-\mathrm{Y} 2}+\mathrm{P}_{\mathrm{OCT}-\mathrm{Y} 1}+0.99 * \mathrm{Tm}_{\mathrm{JUL}-\mathrm{Y} 1}-2.583$ & 0.042 & 5.72 & 0.53 & 10.95 & 0.55 \\
\hline 5 & Yield $=0.07 * \mathrm{SWS}_{\mathrm{APR}-\mathrm{Y} 2}+0.516 * \mathrm{Tm}_{\mathrm{JUN}-\mathrm{Y} 2}-0.856 * \mathrm{Tm}_{\mathrm{OCT}-\mathrm{Y} 1}+24.882$ & 0.042 & 6.40 & 0.53 & 18.72 & 0.71 \\
\hline \multicolumn{7}{|c|}{ Mogi Mirim } \\
\hline 1 & Yield $=-0.056 * \mathrm{DEF}_{\text {JUL-Y2 }}-0.029 * \mathrm{P}_{\mathrm{APR}-\mathrm{Y} 2}-0.567 * \mathrm{Tm}_{\mathrm{OCT}-\mathrm{Y} 1}+8.553$ & 0.007 & 2.04 & 0.72 & 6.40 & 0.70 \\
\hline 2 & Yield $=-0.028 * \mathrm{P}_{\mathrm{APR}-\mathrm{Y} 2}-0.835 * \mathrm{Tm}_{\mathrm{JUL}-\mathrm{Y} 2}-0.028 * \mathrm{Tm}_{\text {OCT-Y1 }}+23.890$ & 0.005 & 2.42 & 0.75 & 6.43 & 0.60 \\
\hline 3 & Yield $=-0.022 * \mathrm{P}_{\text {APR-Y2 }}-0.589 * \mathrm{Tm}_{\text {JUL-Y2 }}+0.451 * \mathrm{Tm}_{\mathrm{AUG}-\mathrm{Y} 1}+22.088$ & 0.027 & 2.82 & 0.59 & 7.87 & 0.77 \\
\hline 4 & Yield $=-0.941 * \mathrm{Tm}_{\mathrm{JUL}-\mathrm{Y} 2}+0.019 * \mathrm{EXC}_{\mathrm{MAR}-\mathrm{Y} 1}-1.523 * \mathrm{Tm}_{\mathrm{FEB}-\mathrm{Y} 1}+71.821$ & 0.034 & 3.24 & 0.56 & 8.84 & 0.89 \\
\hline 5 & Yield $=-0.038 * \mathrm{DEF}_{\mathrm{JUL}-\mathrm{Y} 2}-0.025 * \mathrm{P}_{\mathrm{APR}-\mathrm{Y} 2}+0.425 * \mathrm{Tm}_{\mathrm{APR}-\mathrm{Y} 1}+11.759$ & 0.040 & 3.24 & 0.53 & 8.94 & 0.61 \\
\hline \multicolumn{7}{|c|}{ Registro } \\
\hline 1 & Yield $=-0.02 * \mathrm{EXC}_{\mathrm{FEB}-\mathrm{Y} 2}+0.389 * \mathrm{DEF}_{\mathrm{MAY}-\mathrm{Y} 1}+0.035 * \mathrm{P}_{\mathrm{MAY}-\mathrm{Y} 1}+11.706$ & 0.029 & 6.01 & 0.58 & 3.11 & 0.87 \\
\hline & Yield $=0.008 * \mathrm{P}_{\mathrm{JAN}-\mathrm{Y} 2}+0.057 * \mathrm{SWS}_{\mathrm{MAY}-\mathrm{Y} 2}-0.014 * \mathrm{P}_{\mathrm{JUL}-\mathrm{Y} 1}+9.013$ & 0.035 & 6.49 & 0.55 & 8.02 & 0.64 \\
\hline 3 & Yield $=0.021 * \mathrm{P}_{\mathrm{JAN}-\mathrm{Y} 2}+0.114 * \mathrm{DEF}_{\mathrm{APR}-\mathrm{Y} 1}-0.019 * \mathrm{P}_{\mathrm{JUL}-\mathrm{Y} 1}+8.656$ & 0.002 & 4.58 & 0.82 & 8.51 & 0.66 \\
\hline & Yield $=0.014 * \mathrm{P}_{\text {JAN-Y2 }}-0.024 * \mathrm{P}_{\text {MAR-Y1 }}-0.016 * \mathrm{P}_{\text {JUL-Y1 }}+15.512$ & 0.030 & 6.59 & 0.57 & 9.60 & 0.70 \\
\hline 5 & Yield $=-0.013 * \mathrm{P}_{\mathrm{FEB}-\mathrm{Y} 2}-0.066 * \mathrm{P}_{\mathrm{APR}-\mathrm{Y} 1}-0.016 * \mathrm{P}_{\mathrm{JUL}-\mathrm{Y} 1}+23.968$ & 0.044 & 7.10 & 0.52 & 11.20 & 0.87 \\
\hline
\end{tabular}

MAPE: mean absolute percentage error; SWS: soil water storage (mm); Tm: mean air temperature $\left({ }^{\circ} \mathrm{C}\right)$; DEF: water deficiency (mm); P: precipitation (mm); JAN-Y1: month of the development year (year 1); JAN-Y2: month of the production year (year 2).
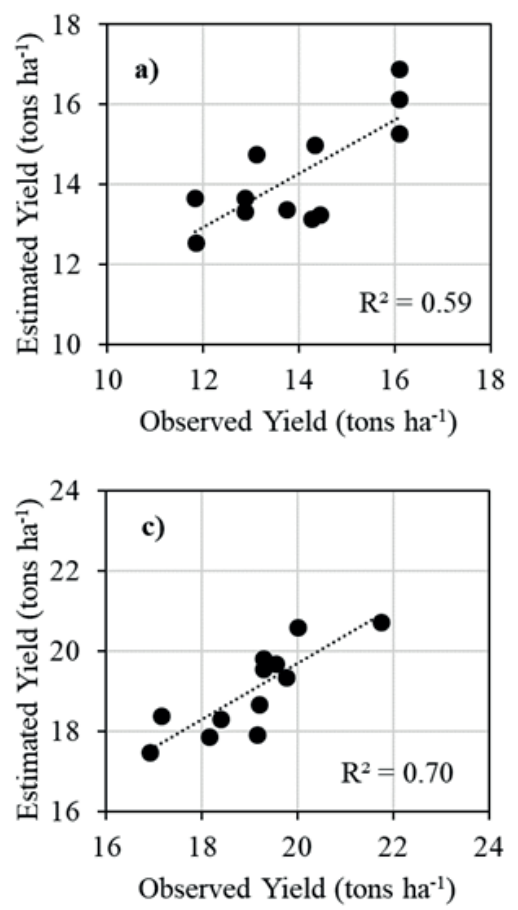
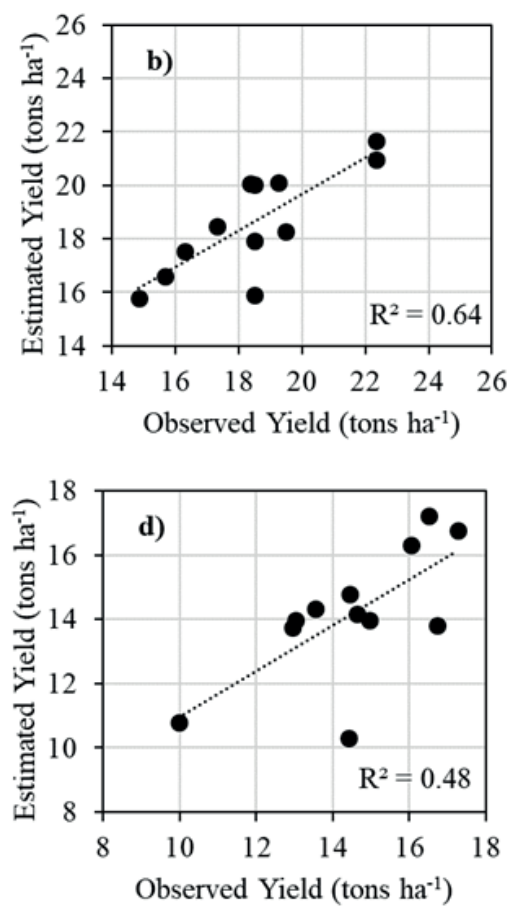

Figure 4. Model calibration for estimating the cassava yield for the São Paulo state. Region (model number on Table 1): a) Jaboticabal (1); b) Assis (1); c) Mogi Mirim (4); d) Registro (1). 
The mean air temperature had a higher frequency and higher coefficients for all regions, mainly during the periods of physiological dormancy and harvest (January to July). Jaboticabal and Assis showed an inverse relationship, while, for Mogi Mirim and Registro, it was direct. An inverse relation indicates that an increase of air temperature is deleterious to the final yield, and a direct relation favors the final yield.

Generally, air temperature is one of the most important meteorological elements that affect the

Table 2. Months of anticipation of the models for cassava yield estimation.

\begin{tabular}{|c|c|c|c|c|c|c|}
\hline \multirow{2}{*}{ Region } & \multicolumn{6}{|c|}{ Year 2} \\
\hline & FEB & MAR & $\mathrm{APR}$ & MAY & JUN & JUL \\
\hline Jaboticabal & & & A, B & & & \\
\hline Assis & & & A & & B & \\
\hline Mogi Mirim & & & & & & $\mathrm{A}, \mathrm{B}$ \\
\hline Registro & A & & & $\mathrm{B}$ & & \\
\hline
\end{tabular}

A: maximum anticipation; B: best model (calibration) anticipation.
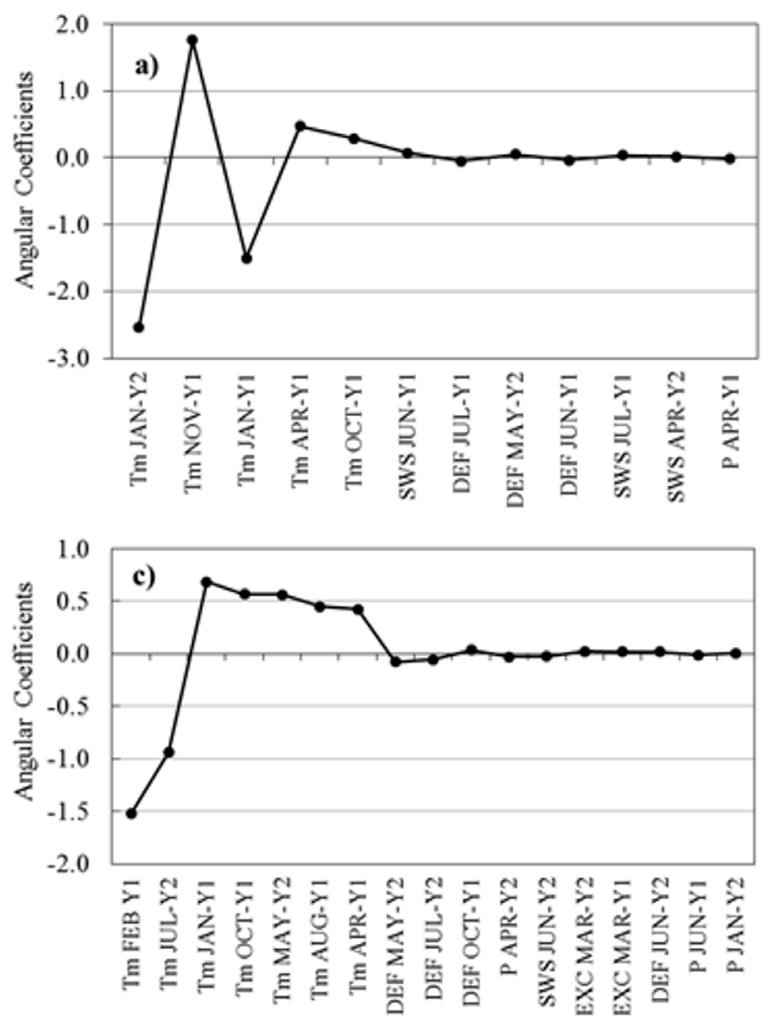

cassava development (Streck 2002). At the end of the tuber bulking, and mainly at the vegetative growth (November), if temperature decreases, the formation of leaves also decreases (Schons et al. 2007). According to Fagundes et al. (2007), high temperatures during the starch accumulation phase (January) slow the leaf senescence, harming the initial starch concentration. Higher temperatures at harvest, associated with lower water supply, increase the soil resistance, making more difficult the lifting of roots from the soil. This reduces the harvest efficiency by increasing the lifting force and causing damage to the roots (Agbetoye et al. 1998).

With the objective of synthesizing the information about the effects of the variables on sweet cassava yield, an analysis of variable frequency and coefficients was conducted with all the models of the producing regions of the state, and showed that the mean air temperature during the whole cycle and the water deficit and soil water storage at the beginning and end of the cycle are the most influential meteorological variables for the production in the
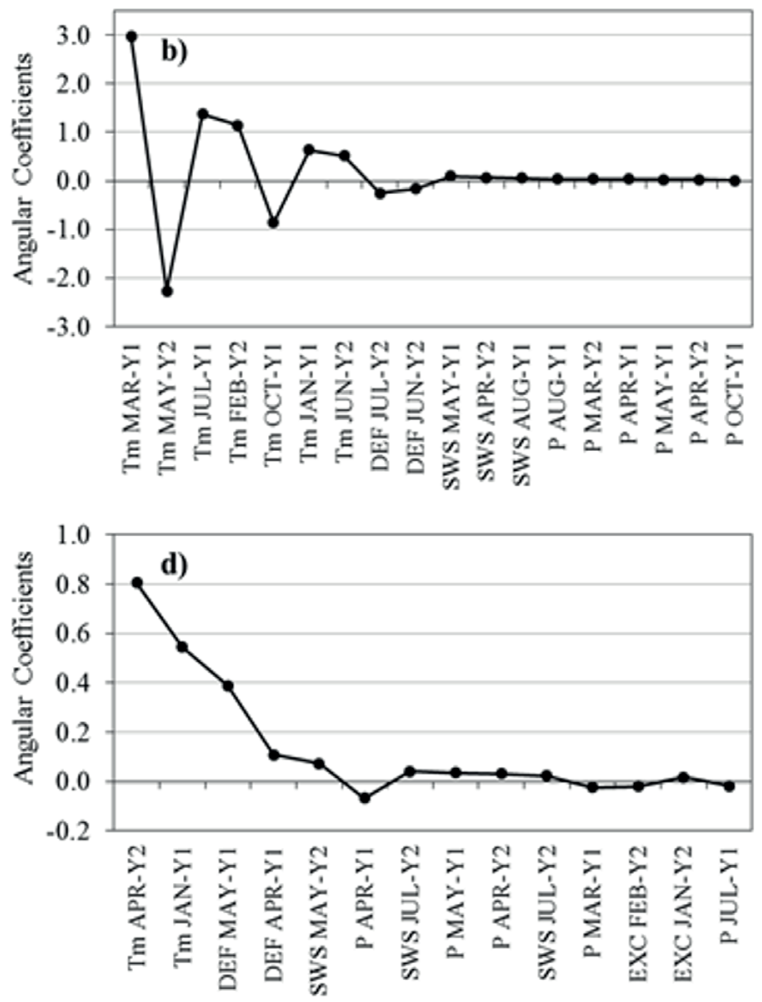

Figure 5. Angular coefficient of the most influential independent variables adjusted for the ten best models to estimate the sweet cassava yield in the regions of Jaboticabal (a), Assis (b), Mogi Mirim (c) and Registro (d). Tm: mean air temperature; SWS: soil water storage; DEF: water deficiency; EXC: water excess; P: precipitation; Y1: indicates variables from the development year; Y2: indicates variables from the production year. 


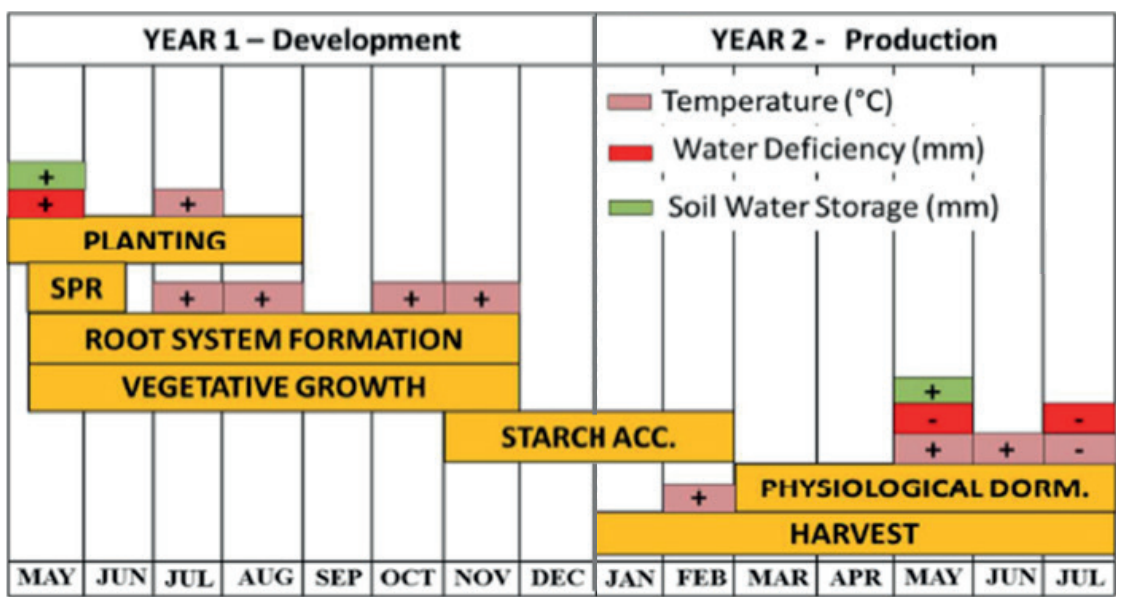

Figure 6. Influence of the main meteorological variables (higher angular coefficients during the cassava crop cycle, as detected by the models for estimating the sweet cassava yield in the São Paulo state) and the phenological phase they affect. SPR: sprouting; STARCH ACC: starch accumulation; PHYSIOLOGICAL DORM: physiological dormancy; $(+)$ indicates a direct relation; (-) indicates an inverse relation.

São Paulo state (Figure 6). One of the reasons for the high tolerance of cassava during dry periods is its highly sensitive stomatal system. In low moisture soil conditions, the plant saves water by controlling transpiration; however, long periods with severe dry spells during the cycle decrease yield (Oliveira et al. 1982, Okogbenin et al. 2013).

Air temperatures in October and November, during phases of tuber bulking, vegetative growth and the beginning of starch accumulation were the other variables that had a large influence on sweet cassava yield, with a direct relation $(+)$. At these phases, temperatures directly affect leaf senescence, thus favoring the root dry matter accumulation, which is higher during this period (Peressin et al. 1998).

\section{CONCLUSIONS}

1. The regional agrometeorological models were significant and showed a strong capacity to estimate the sweet cassava yield before harvest. The highest accuracy for each region was $3.11 \%$ for Registro, $6.40 \%$ for Mogi Mirim, $7.15 \%$ for Jaboticabal and $8.08 \%$ for Assis;

2. The most influent variables for the São Paulo state, during the sweet cassava cycle, are mean air temperature, water deficiency and soil water storage. The mean air temperature is the most important meteorological element, mainly in periods of physiological dormancy and harvest (January to July).

\section{REFERENCES}

AgBetoye, L. A. S.; Kilgour, J.; DYSON, J. Performance evaluation of three pre-lift soil loosening devices for cassava root harvesting. Soil and Tillage Research, v. 48, n. 4, p. 297-302, 1998.

ALVES, A. A. C. Fisiologia da mandioca. In: EMBRAPA MANDIOCA E FRUTICULTURA TROPICAL. Aspectos socioeconômicos e agronômicos da mandioca. Cruz das Almas: Embrapa, 2006. p. 138-169.

CAPORUSSO, N. B.; ROLIM, G. S. Reference evapotranspiration models using different time scales in the Jaboticabal region of São Paulo, Brazil. Acta Scientiarum Agronomy, v. 37, n. 1, p. 1-9, 2015.

COMPANHIA NACIONAL DE ABASTECIMENTO (Conab). Levantamento safra 2015-2016. 2017. Available at: <http://www.conab.gov.br>. Access on: 16 Feb. 2018.

CORREA, S. T. R. et al. Aplicações e limitações da modelagem em agricultura: revisão. Revista de Agricultura, v. 86, n. 1, p. 1-13, 2011.

DOORENBOS, J.; KASSAM, A. H. Efeito da água no rendimento das culturas. Campina Grande: UFPB, 1994.

FAGUNDES, L. K. et al. A fenologia da mandioca em diferentes épocas de cultivo em local de clima subtropical. Raizes e Amidos Tropicais, v. 3, n. 1, p. 1-4, 2007.

FOOD AND AGRICULTURE ORGANIZATION OF THE UNITED NATIONS (FAO). Faostat database collections. Rome: FAO, 2012.

FOOD AND AGRICULTURE ORGANIZATION OF THE UNITED NATIONS (FAO). Save and grow cassava: 
a guide to sustainable production intensification. Rome: FAO, 2013.

GABRIEL, L. F. et al. Mudança climática e seus efeitos na cultura da mandioca. Revista Brasileira de Engenharia Agrícola e Ambiental, v. 18, n. 1, p. 90-98, 2014.

GUJARATI, D. N.; POTER, D. C. Econometria básica. 5. ed. Porto Alegre: AMGH, 2011.

INSTITUTO BRASILEIRO DE GEOGRAFIA E ESTATÍSTICA (IBGE). Levantamento sistemático da produção agrícola. 2016. Available at: $<$ https://www.ibge. gov.br/estatisticas-novoportal/economicas/agricultura-epecuaria.html>. Access on: 26 Feb. 2018.

LAHAI, M. T.; GEORGE, J. B.; EKANAYAKE, I. J. Cassava (Manihot esculenta Crantz) growth indices, root yield and its components in upland and inland valley ecologies of Sierra Leone. Journal of Agronomy and Crop Science, v. 182, n. 4, p. 239-248, 1999.

MEZZETTE, T. F. et al. Selection of sweet cassava elite-clones for agronomical, technological and chemical characteristics. Bragantia, v. 68, n. 3, p. 601609, 2009.

MORETO, V. B.; ROLIM, G. S. Estimation of annual yield and quality of 'Valência' orange related to monthly water deficiency. African Journal of Agricultural Research, v. 10 , n. 6 , p. 543-553, 2015.

OKOGBENIN, E. et al. Phenotypic approaches to drought in cassava: a review. Frontiers in Physiology, v. 4, n. 93, p. 1-15, 2013.

OLIVEIRA, S. L.; MACEDO, M. M. C.; PORTO, M. C. M. Efeito do déficit de água na produção de raízes de mandioca. Pesquisa Agropecuária Brasileira, v. 17, n. 1, p. 121-124, 1982.

PERESSIN, V. A. et al. Effects of weed interference on cassava growth and productivity. Bragantia, v. 57, n. 1, p. 135-148, 1998.

RIJKS, D.; BARADAS, M. W. The clients for agrometeorological information. Agricultural and Forest Meteorology, v. 103, n. 1, p. 27-42, 2000.

RÓS, A. B. et al. Cassava cultivars growth, phenology and yield. Pesquisa Agropecuária Tropical, v. 41, n. 4, p. 552-558, 2011.
SÃO PAULO. Coordenadoria de Assistência Técnica Integral (CATI-LUPA). Levantamento censitário das unidades de produção agropecuária do estado de São Paulo. 2008. Avaible at: <http://www.cati.sp.gov.br/ projetolupa/mapaculturas/Mandioca.php $>$. Access on: 13 Feb. 2018.

SCHONS, A. et al. Emissão de folhas e início de acumulação de amido em raízes de uma variedade de mandioca em função da época de plantio. Ciência Rural, v. 37, n. 6, p. 1586-1592, 2007.

STRECK, N. A. A generalized nonlinear air temperature response function for node appearance rate in muskmelon (Cucumis melo L.). Revista Brasileira de Agrometeorologia, v. 10, n. 1, p. 105-111, 2002.

THORNTHWAITE, C. W. An approach towards a rational classification of climate. Geographical Review, v. 38, n. 1, p. 55-94, 1948.

THORNTHWAITE, C. W.; MATHER, J. R. The water balances. Centerton: Drexel Institute of Technology, 1955.

TREMACOLDI, C. R. Manejo das principais doenças da cultura da mandioca no estado do Pará. In: MODESTO JUNIOR, M. S.; ALVES, R. N. B. (Eds.). Cultura da mandioca: aspectos socioeconômicos, melhoramento genético, sistemas de cultivo, manejo de pragas e doenças e agroindústria. Brasília, DF: Embrapa, 2016. p. 162-170.

VALLE, T. L. et al. Cyanide and acid content in progenies from crosses of bitter and sweet cassava cultivars. Bragantia, v. 63, n. 2, p. 221-226, 2004.

VALLE, T. L. et al. Mandioca: energia e alimento para o mundo. O Agronômico, v. 59, n. 1, p. 29-31, 2007.

VALLE, T. L.; LORENZI, J. O. Improved varieties of cassava as a tool of innovation, food safety, competitiveness and sustainability: contributions of the Agronomic Institute of Campinas (IAC). Cadernos de Ciência e Tecnologia, v. 31, n. 1, p. 15-34, 2014.

WALPOLE, R. E.; MYERS, R. H.; MYERS, S. L. Probability \& statistics for engineers \& scientists. 9. ed. Boston: Pearson Education, 2012.

ZANETTI, E. G. B. et al. Performance of two cassava varieties submitted to different spacings, grown in the Cerrado region. Brazilian Journal of Applied Technology for Agricultural Science, v. 7, n. 1, p. 39-46, 2014. 